\title{
Authoritarianism and authority: from health to society
}

\section{Author:}

Dr. Marcelo Simões Mendes

Professor at the Sao Francisco University / Brazil

Adress: Av São Francisco de Assis, 218. Bragança Paulista, S.P., Brazil. CEP:12916900

E-mail:m_smendes@outlook.com

\begin{abstract}
Most of the time, the authority's phenomenon has been distorted and has been totalized and reduced with the same meaning of the authoritarianism. Especially in sensible moments that have impacted a massive number of people - like the novel coronavirus (2019-nCoV) -, it is many common distortions be potentialized. The current essay aimed to present some relationships between authority and authoritarianism in a scenario dichotomized by the left and right political positions. It is an opportunity to enlightening some structural processes of alienation and collaborated with more evident perspectives about social development, from health to society.
\end{abstract}

Keywords: authority; personality; mental health.

\section{Compliance with Ethical Standards}

Funding: There is no funding in this manuscript.

Conflict of Interest: Author Marcelo Simões Mendes declares that he has no conflict of interest.

Ethical approval: This article does not contain any studies with human participants or animals performed by any of the authors. 


\section{Authoritarianism and authority: from health to society}

Despite the severe consequences and hard damages in many episodes throughout history (e.g., world wars, terrorist attacks), several advances for humanity were accomplished these same moments. From this perspective, the purpose of this essay is not to incentive the simplistic conception of more disaster; the more progress the world will have. Even so, the reflections presented below intend to cultivate some learnings of the many lessons that the coronavirus presents to humanity.

The provocative comment of Kavanagh (2020) recaptures a dilemma that is not only present in the health domain but, in fact, that cross many dimensions of life in contemporaries' societies: the constitution, the role, and the consequences of the authoritarianism' conduct. According to Kavanagh (2020), the Chinese government presented efficiency by its authoritarian actions in tackling the 2019-nCoV outbreak. Even though the initial actions in China may be considered dubious (Kupferschmidt, 2020), the author's mature posture (Kavanagh, 2020) indicated the vantages and disadvantages of democratic and autocratic systems.

Although the difficulty of defining politics and economic positions in postmodernity (Bauman, 1992), from a traditional perspective, the world has been divided into two sides: left (Horkheimer et al., 2002; Marx, 1992, 1995) and right. (von Mises, 1985, 1994; von Mises and Raico, 1985) This same tradition conception was used to alienate people that all ideologies and actions from left comprise revolutionary, righteous, and egalitarian's principles. On the other hand, the 'right side' implies domination, the traditional - and retrograde culture -, the authoritarianism.

From this distorted comprehension cited above, the left has been recognized as the side that defends and respects diversity. The authority's positions represent the most 
aversive symbol for humanity, the biggest enemy. One way that this understanding has been strengthened by giants' media and educational systems around the world is not to distinguish authority from authoritarianism.

On the ideologies' domain, a way to 'combat' the alienation is on maturing and qualifying the hidden spaces between a phenomenon and others. That authoritarianism brought terrible consequences for humanity (e.g., Nazism, slavery). However, the authority's principles were and are crucial to the development of societies - including stopping many wars and guarantee human rights.

From the psychoanalytic perspective (Freud, 1989), some domains of subjectivity can just be accessed by an authority figure. These domains are not strictly related to insanity behaviors but with principles of morality and, thus, related to the healthy development of individuals.

Therefore, the authoritarianism cannot be confused with authority. Many factors foster violence, intolerance, and deplorable situations. One of these does not specify the characteristics of different phenomena, assigning an understanding as if they were equivalent. Concomitant with the pandemic event that the world is living today is the 'ideological war' between left and right. It seems an excellent opportunity to advanced in many domains of the world community, including the relationships between health and society.

\section{References}

Bauman, Z. (1992) Intimations of Postmodernity. London: Routledge.

Freud, S. (1989) The Ego and the Id. New York: W. W. Norton \& Company. 
Horkheimer, M., Adorno, T., Noeri, G. and Jephcott, E. (2002) Dialectic of Enlightenment. Redwood City: Stanford University Press.

Kavanagh, M.M. (2020) Authoritarianism, outbreaks, and information politics. The Lancet Public Health 5: e135-e136.

Kupferschmidt, K. (2020) Mission impossible? WHO director fights to prevent a pandemic without offending China. Science.

von Mises, L. (1985) Omnipotent Government: the rise of the total state \& total war. Grove City: Libertarian Press.

von Mises, L. (1994) The Anticapitalistic Mentality. Grove City: Libertarian Press. von Mises, L. and Raico, R. (1985) Liberalism in the Classical Tradition. Cobden Press.

Marx, K. (1992) The Communist manifesto. New York: Oxford University Press.

Marx, K. (1995) The Capital I. Moscow: Progress Publishers. 